\title{
Use of Water by Schoolchildren: Impact of Indirectly Supervised Daily Toothbrushing: A Pilot Study
}

\author{
Flávia Martão Flório ${ }^{1}$, Letícia dos Santos $\mathrm{Klee}^{2}$, Ana Paula Brandão Ramos ${ }^{3}$, Gláucia Maria Bovi Ambrosano ${ }^{4}$,
} Almenara de Souza Fonseca Silva ${ }^{5}$

\begin{abstract}
Aim: This present longitudinal, quantitative, and analytical pilot study evaluated the impact of daily indirectly supervised toothbrushing on water consumption.

Materials and methods: The study was carried out in a social center that provided care to children aged 5-14 years in Campinas in the state of São Paulo. Calibrated hydrometers were installed on taps used by the children, and the daily volume of water used was measured for 25 school days (T0). An educational program was then implemented (T1), where supervised toothbrushing was explained, encouraged, and put into action. The next phase (T2) incorporated a recreational approach to the rational use of water, and the consumption was measured for another 25 school days. After six months (T3) without further educational interventions by the researchers, water consumption was measured for the same period of 25 school days. The data were analyzed based on the mixed models methodology for measures repeated over time.

Results: The water consumption did not change significantly $(p>0.05)$ between the different phases of the study $(\mathrm{T} 0=0.43 \pm 0.19, \mathrm{~T} 1=0.38$ $\pm 0.17, \mathrm{~T} 2=0.39 \pm 0.15, \mathrm{~T} 1=0.48 \pm 0.21 \mathrm{dm}^{3} /$ day $/$ child $)$.

Conclusion: The introduction of toothbrushing into the routine of the children, in the context of recreational and sustainable health education, did not have a detrimental impact on water consumption.

Clinical significance: Among the many recommendations for the introduction and implementation of supervised toothbrushing programs in school environments, there is no mention of the measures taken during such procedures aimed at economizing water, the rational use of which should be a daily practice irrespective of the water conditions of the surrounding region. The findings of this study contribute to the enhancement of educational and pedagogical activities in schools.
\end{abstract}

Keywords: Child, Conservation of water resources, Oral Health, Water consumption (environmental health), Water resources.

International Journal of Clinical Pediatric Dentistry (2020): 10.5005/jp-journals-10005-1800

\section{INTRODUCTION}

Water, which is the principal substance for sustaining life, ${ }^{1}$ is a limited natural resource, and by 2030, the world will face a water shortage of $40 \% .^{2}$ While Brazil is privileged in terms of water resources, possessing $12 \%$ of the world's freshwater, ${ }^{3}$ the poor distribution of resources and the low quality of water available in cities is a problem. ${ }^{4,5}$ In 2015 , the country experienced the continuation of one of the most severe droughts in the last 50 years from a meteorological, water, and agricultural perspective, with the most critical period occurring between 2012 and $2014 .^{6}$ It is estimated that São Paulo will be one of the ten cities in the world to suffer water shortages by $2030 .^{2}$

The first signs of the Brazilian water crisis began in 2004 in the most populous state in the country, when the São Paulo State Sewage Company (SABESP) announced that there was insufficient water storage capacity available due to the increase in consumption. Ten years later, the useable volume of water in the Cantareira system ran out and São Paulo faced the most serious water crisis in the last 80 years. ${ }^{7}$

The education sector in the south-east of Brazil then began to seek options to help save water in the day-to-day running of its education centers, involving student awareness ${ }^{8}$ in addition to checking and repairing leaks and changing flush valves in toilets, old drinking fountains, and taps. ${ }^{8-10}$ Among the impacts on health, water shortages and/or the need to save water can mean that it is impossible to carry out certain sanitation and hygiene measures. ${ }^{11}$ Due to the crisis, some of the actions taken to economize water affect the representation of the school as a social environment,
${ }^{1}$ Department of Preventive Dentistry, Faculdade São Leopoldo Mandic, Campinas, SP, Brazil; Department of Public Health, São Leopoldo Mandic School of Dentistry and Research Center, Campinas, Brazil

${ }^{2}$ Department of Public Health, Faculdade São Leopoldo Mandic, Campinas, São Paulo, Brazil

${ }^{3}$ Simplific Consultancy and Advisory in Health, Safety and Environment, Campinas, São Paulo, Brazi

${ }^{4}$ Department of Social Preventive Dentistry, Piracicaba School of Dentistry (UNICAMP), Piracicaba, São Paulo, Brazil

${ }^{5}$ Dental Clinics Department, Faculdade São Leopoldo Mandic, Campinas, São Paulo, Brazil

Corresponding Author: Flávia Martão Flório, Department of Preventive Dentistry, Faculdade São Leopoldo Mandic, Campinas, SP, Brazil; Department of Public Health, São Leopoldo Mandic School of Dentistry and Research Center, Campinas, Brazil, Phone: +55 19999087533, e-mail: flaviaflorio@yahoo.com

How to cite this article: Flório FM, dos Santos Klee L, Brandão Ramos AP, et al. Use of Water by Schoolchildren: Impact of Indirectly Supervised Daily Toothbrushing: A Pilot Study. Int J Clin Pediatr Dent 2020;13(5):513-517.

Source of support: Nil

Conflict of interest: None

which due to offering extrafamiliar influences ${ }^{12}$ and the amount of time children spend there provides an opportunity to carry out behavioral interventions. ${ }^{13}$ Among such harmful actions, in Santo André in the state of São Paulo, the proposed water saving proved 
controversial by restricting the amount of toothbrushing carried out in schools. ${ }^{8}$ More worryingly, in municipalities and in the state such as Mairinque and São Paulo, toothbrushing was prohibited. ${ }^{14,15}$

Health education is considered as the health promotion strategy aimed at promoting changes in the knowledge, attitudes, and skills of individuals. Although several authors have described and proven the importance of Health Education Programs in schools, both in the acquisition of new knowledge ${ }^{12}$ and behaviors in relation to oral health, ${ }^{13}$ as well as in reducing indices of oral illnesses, ${ }^{16-20}$ health education remains a challenge for the education sector, in terms of the possibility of ensuring an effective transformation in attitudes and living habits. ${ }^{21-23}$

In this context, among the many recommendations for the introduction and implementation of supervised toothbrushing programs in school environments, ${ }^{23-25}$ there is no mention of the measures taken during such procedures aimed at economizing water, the rational use of which should be a daily practice irrespective of the water conditions of the surrounding region. The objective of the present study was therefore to evaluate the impact on water consumption of the introduction of a daily routine of indirect supervised toothbrushing in the context of recreational and sustainable health education.

\section{Materials and Methods}

The present longitudinal, quantitative, and analytical study was conducted in accordance with the precepts established by Resolution 466 dated 2012 and was approved in accordance with CAAE 3383616.9.0000.5374.

The study was developed in a social center located in Campinas, a city in the northwest of the state of São Paulo, with a population of 1,080,113 (IBGE, 2010). It is the third most populous municipal district in the state and has a high Human Development Index $(\mathrm{HDI}=0.805)$. The center in question operates outside the regular school hours to provide a care option for parents and guardians who work full-time. During the study period, 47 students of both genders were enrolled in the two daily sessions of the center and participated in the educational activities.

An on-site visit was performed to inspect and survey the existing sinks in the bathrooms used for the oral hygiene of the children and to verify which hygiene and cleaning activities were performed routinely and frequently. A professional inspection when the hydrometers were installed confirmed the absence of leaks. Toothbrushing was not routinely performed because the social center did not have toothbrushes for the children, and the use of toilets was a priority for the children between 08:00 and 17:00. These toilets are the only ones of children's use in the center.

\section{Measurement of Water Consumption and Study Phases}

The water consumption in sinks was measured through the installation of calibrated hydrometers (Unimag TU III $3.0 \mathrm{~m}^{3} / \mathrm{h}$ DN $203 / 4$ 'Class B-H) in the pipes that supplied water to the taps for the male and female bathrooms. The volume was measured daily at the beginning (08:00) and at the end of school activities for the day (17:00), for 25 school days, establishing the baseline of the study (T0). At the end of this phase, the educational program began and its impact on the consumption of water was measured at three other points ( $T 1, T 2$, and $T 3)$, respecting the measuring criteria adopted for T0.
At the end of T0, health education was performed on a regular basis. The oral health activities focused on traditional self-care procedures, and following the distribution of oral hygiene kits, a daily indirect supervised brushing routine was established after the main meal of the period. Rational water use was not addressed during this phase. After the educational activities were carried out with the participation of all the children, water consumption was measured for 25 school days (T1).

After the supervised toothbrushing routines were established, two months after the start of the T1 phase, further educational activities were carried out focusing on rational water consumption. After these sessions, water consumption was measured for another 25 school days (T2).

Six months after the end of $\mathrm{T} 2$, without further intervention from researchers in the school routine, water consumption was assessed for an additional 25 school days (T3). At the beginning of this final phase of the study, new oral hygiene kits were distributed to children.

In all the phases, the daily attendance of the students was registered, by gender, thus allowing the calculation of daily water consumption per child.

\section{Educational Activities in Oral Health}

The educational activities were based on the pedagogical strategies described in the book Learning about Health through Play Sustainable Oral Health for Children ${ }^{26}$ which is based on sustainability and describes the use of eco-games and eco-objects made from domestic waste materials as learning tools to encourage children to practice self-care. The concepts developed in the book, in addition to promoting the awareness of fundamental values among children, also encourage the responsibility for their own health and the environment. The educational program was composed of four weekly sessions, carried out in both daily periods to include children who attended the center in the morning and afternoon, according to the following themes: Session 1: health as a whole and the parts of the mouth, their function and importance; Session 2: the most common diseases of the mouth: cause and consequence; Session 3: the importance of good nutrition; Session 4: a well-trained, helping hand.

In this phase, all the children received oral hygiene kits containing a toothbrush, toothpaste, and dental floss. After each session, they were instructed in their use and monitored through a direct supervised toothbrushing procedure. Daily supervised brushing was carried out after the main meal of each period, supervised by a monitor from each class, who recorded the procedure, per day, per child, and in all phases of the study, in order to record and calculate the actual performance of brushing.

In the next phase (T2), the use of water in a rational manner was addressed, without affecting the use of fluoridated dentifrice in the prevention of the emergence and development of dental caries: the importance of opening the tap just enough to slightly wet and rinse the brush and quickly rinse the mouth using cupped hands was emphasized. The strategy of raising awareness of the problem was based on the dynamics presented in the Water Project video (https:// goo.gl/37bz4D), when, during the trailers, cinemagoers received sealed bottles of mineral water and, when their dissatisfaction became clear, were shown a video that emphasized the difficulty many people suffer in terms of access to water.

In the present study, bottles of mineral water with preglued lids were distributed to the children in a recreational period. When 
they grew tired of trying to open the lid, a video produced by the researchers was shown, with adaptations for the age group and addressing the problem of the present study. The video entitled "Water Is Life" (https://youtu.be/A2UIKtwEkKk) lasts for 7 minutes and 17 seconds and has a catchy soundtrack and language aimed at children. It features three phases, the first of which addresss the difficulty that many people face when accessing water, which, when available, is often of poor quality. In the second phase, examples of waste found in the daily routine were shown, while the third phase included proposals to rethink the daily use of water. There was an emphasis on illustrating the maximum possible number of situations in which children can make a difference. At the end, toothbrushing and care when opening and closing taps were explained.

After the video, the reasons for gluing the caps of the bottles were explained, questions about the video were answered, and an eco-object tap was used ${ }^{27}$ to provide a dynamic demonstration of the correct time to open or close a tap. In groups, the children made posters to display in the male and female bathroom to remind them of the importance of economizing water.

\section{Data Analysis}

Based on the daily attendance of students, the total and average volume of water used in the sinks per child was calculated. An exploratory analysis of the data involving a logarithmic transformation was performed so that the total consumption data met the presuppositions of a parametric analysis. The mixed models methodology for measures repeated over time was applied, considering a level of significance of $5 \%$. The effect size $(E S)$ in the phases of the study, considering the genders and total number of students, was calculated by Cohen's f. ${ }^{28}$ The effect size in the present study represents the magnitude of the effect of the interventions (educational and evaluation periods) in relation to variation by chance (noncontrollable variation, between the 25 days of the same period).

\section{Results}

Table 1 summarizes the findings for each phase of the study, represented by the mean and standard deviation of water consumption ( $\left.\mathrm{dm}^{3} / \mathrm{day} / \mathrm{child}\right)$, in each period. Based on the results of the $p$ values $(p>0.05)$ and the calculated effect sizes (small effect $\operatorname{size}^{28}$ ), the null hypothesis was not rejected, i.e., water consumption was not influenced by the proposed educational actions and the introduction of daily supervised toothbrushing in school, either among the different genders or overall.

\section{Discussion}

Environmental planning for the rational use and prevention of the eradication of water resources are fundamental for the preservation of society. ${ }^{29}$ The role of education is of fundamental importance in terms of the future and the conscious consumption of water, ${ }^{3}$ and the biggest challenge for citizens, businesses, and governments is to seek actions that promote sustainable consumption and production. $^{30}$

Schools represent an important social environment for the promotion of oral health, through opportunizing actions of a collective nature and supplementing and supporting behaviors and care practices, which may be consistently provided in the daily domestic routine. ${ }^{31}$ In addition, school children are at an age that
Table 1: Registered water consumption ( $\mathrm{dm}^{3} /$ day/child), considering the phases of the study, in the female and male restrooms and in the social center. Campinas, 2016-2018

\begin{tabular}{|c|c|c|c|}
\hline & Female & Male & Total \\
\hline Study phases & Mean $\pm S D$ & Mean $\pm S D$ & Mean $\pm S D$ \\
\hline T0: Baseline & $0.47 \pm 0.19$ & $0.39 \pm 0.24$ & $0.43 \pm 0.19$ \\
\hline $\begin{array}{l}\text { T1: After educational } \\
\text { activities-supervised } \\
\text { toothbrushing }\end{array}$ & $0.41 \pm 0.21$ & $0.34 \pm 0.15$ & $0.38 \pm 0.17$ \\
\hline $\begin{array}{l}\text { T2: After educational } \\
\text { activities-supervised } \\
\text { toothbrushing }+ \\
\text { rational use of water }\end{array}$ & $0.41 \pm 0.16$ & $0.37 \pm 0.18$ & $0.39 \pm 0.15$ \\
\hline $\begin{array}{l}\text { T3: Follow-up without } \\
\text { intervention }\end{array}$ & $0.46 \pm 0.19$ & $0.42 \pm 0.17$ & $0.48 \pm 0.21$ \\
\hline$p$ value & 0.5634 & 0.5903 & 0.1855 \\
\hline Effect size $f(U)$ & 0.10 & 0.09 & 0.15 \\
\hline
\end{tabular}

can absorb information about how to take care of their bodies. ${ }^{23}$ The implementation of educational and pedagogical activities, involving water-related issues, should be a focus in schools due to their role in training citizens and society, ${ }^{32}$ and because of the possibility that children can make those around them aware of the issue. ${ }^{32-34}$ Schools represent an excellent means of sharing the benefits of employing sustainable techniques. ${ }^{34}$

The present study found that the institutionalization of the daily and indirect supervised brushing in the routine of children, in the recreational and sustainable context, did not result in a significant increase in water consumption, contradicting the decision to prevent supervised toothbrushing in schools to save water. ${ }^{14,15}$ The currently available evidence emphatically recognizes that inadequate control of dental biofilm is the etiological factor behind the major diseases that affect oral health in childhood-caries and gingivitis-and that its regular and frequent removal is capable of affecting the emergence of disease and reducing its progression. ${ }^{19,35}$ The frequency of the use of fluoride dentifrice and the method of rinsing after brushing influence the preventive effect on caries, and it is suggested that fluoridated toothbrushing is performed twice a day without excessive rinsing with water, ${ }^{36,37}$ a concept that should be considered when encouraging children to rapidly perform postbrushing mouthwashing with their hands.

The strategy used in phase T2 mainly sought to make children aware of water conservation, which has the potential to effectively reduce water consumption, as relying solely on increasing the environmental awareness of each individual does not necessarily relate to a reduction in water consumption, as actions carried out by people who are highly ecologically aware can increase the use of water. ${ }^{38}$ It was noted that there was no expected reduction in water consumption in T2, as use was likely to be already low. The conservation and rational use of water in buildings of various categories, including school buildings, have been evaluated with regard to use, recommendations about environmental education, the conditions of their hydrosanitary systems, and the use of water economizing equipment, ${ }^{39}$ as well as actions implemented in schools involving water consumption. These measures have shown that it is possible to reduce water use by $70-90 \%$, if leaks are corrected in both the external and internal networks. If there is a change of equipment to hydromechanical models, the reduction can be $9 \%$ greater. $^{10}$ 
One of the areas in which the present article differs from other studies is that no structural changes were made, and the only action adopted was based on health education, which allowed the actual consumption of water in sinks in the hygiene of the children to be measured, along with the consequent impact of the institutionalization of the routine. It is accepted that in the school environment, the greatest consumption of water is in toilets, especially through flushing followed by the use of taps. The guidelines for the reduction of consumption cite the need to raise awareness about water saving. ${ }^{34,40}$ The study found that water consumption per person (teachers, students, and staff) in municipal and state schools ranged from 25.3 to 28.8 liters per day, including hygiene, cleaning, and feeding activities. ${ }^{34}$ The population consumes a mean of 108.4 liters of water per day, ${ }^{41}$ and the results of the present study indicate that the per capita variation in water consumption in sinks ranged from $0.38 \pm 0.17$ to $0.48 \pm 0.21$ liters/ day/child, which allows the premise that the water consumption in the personal hygiene of the children is low. No reduction in this consumption was identified by the proposed methodology, which did not include structural alterations.

In T3, although there was no significant difference with the water consumption identified in the other phases of the study, there was a trend of increased consumption when the researchers were not present in the routine of the social center. In this sense, permeating the daily routine of people with issues related to sustainability and rational water consumption can be an effective approach, as in the field of behavioral actions; regarding the use of taps, it was found that consumption will be higher or lower depending on the flow rate that the user chooses, that is, the number of times they turn the tap and the time it remains open. In this sense, it is perceived that the degree of awareness about the value of water, its scarcity, and declining levels is increasing and can lead to changes in behavior patterns. ${ }^{42}$

One limitation of this study was that it took place at a single institution, so the results may not be generalizable to other center or school. In this context, future studies are needed to determine if the results were limited to our site or are indicative of more widespread phenomena.

The results of this pilot study can be understood from two perspectives: the educational proposal was not effective in reducing water consumption in school, probably due to the absence of the structural changes already addressed and the low consumption identified. At the same time, it contributes to the knowledge that the introduction of daily supervised brushing in the routine of the children, in the context of recreational and sustainable health education, did not negatively affect the water consumption, during the evaluation period, and the prohibition of this procedure based on the justification of saving water is therefore unacceptable.

\section{Conclusion}

The findings of this pilot study suggest that the introduction of toothbrushing into the routine of the children, in the context of recreational and sustainable health education, did not have a detrimental impact on water consumption.

\section{Clinical Significance}

Among the many recommendations for the introduction and implementation of supervised toothbrushing programs in the school environments, there is no mention of the measures taken during such procedures aimed at economizing water, the rational use of which should be a daily practice irrespective of the water conditions of the surrounding region. The findings of this study contribute to the enhancement of educational and pedagogical activities in schools.

\section{ACKnOWLedgments}

The authors would like to thank Faculdade São Leopoldo Mandic for the scholarship granted to the graduate student participating in the study. They would also like to thank the Centro Social Bertoni that allowed the study to be carried out.

\section{References}

1. ICWE, International conference on water and the environment - The Dublin Statement and Report of the Conference; 26-31 January; Dublin, Ireland: WMO, Geneve, Switzerland, 1992.

2. WWAP, (United Nations World Water Assessment Programme). The United Nations World Water Development Report 2015: Water for a Sustainable World. Paris, UNESCO; 2015. Disponível em: http:// unesdoc.unesco.org/images/0023/002318/231823E.pdf.

3. Consumo sustentável: Manual de educação [suporte eletrônico]. Brasília: Consumers International/MMA/MEC/IDEC, 2005. [acessado 2018 Ago 28]; Disponível em: http://portal.mec.gov.br/dmdocuments/ publicacao8.pdf.

4. Rebouças AC. Água e desenvolvimento rural. Estud av 2001;15(43):327344. Disponível em: 10.1590/S0103-40142001000300024.

5. Augusto LG, Gurgel IG, Câmara Neto HF, et al. The global and national context regarding the challenges involved in ensuring adequate access to water for human consumption. Cien Saude Colet 2012;17(6):1511-1522. DOI: 10.1590/s1413-81232012000600015.

6. Alpino TA, de Sena AR, de Freitas CM. Disasters related to droughts and public health - a review of the scientific literature. Cien Saude Colet 2016;21(3):809-820. DOI: 10.1590/1413-81232015213.21392015.

7. Cohen OO, Fundo do Poço. [online]. 2015. [citado em 2015 jan 10]. Disponível em: http://super.abril.com.br/crise-agua/ofundodopoco. shtml.

8. Fernandjes N, Crise Hídrica Mobiliza Instituições de Ensino. [online]. 2015. [citado em 2015 fev 6]. Disponível em: http://www.dgabc.com. br/Noticia/1201126/crise-hidrica-mobiliza-instituicoes-de-ensino.

9. Gonçalves OM, Ilha MSO, Amorim SV, et al. Indicadores de uso racional de Água para escolas de ensino fundamental e médio. Ambiente Construído 2005;5(3):35-48.

10. Ywashima LA, Avaliação do uso de água em edifícios escolares públicos e análise de viabilidade econômica da instalação de tecnologias economizadoras nos pontos de consumo. [dissertação]. Campinas (SP): Universidade Estadual de Campinas, Campinas, 2005.

11. Grigoletto JC, Cabral AR, Bonfim CV, et al. Management of health sector actions in drought situations. Cien Saude Colet 2016;21(3):709718. DOI: 10.1590/1413-81232015213.26212015.

12. Pérez-Rodrigo C, Aranceta J. Nutrition education in schools: experiences and challenges. Eur J Clin Nutr 2003;57(Suppl 1):S82-S85. DOI: $10.1038 /$ sj.ejcn.1601824.

13. Abdel Rahman A, Jomaa L, Kahale LA, et al. Effectiveness of behavioral interventions to reduce the intake of sugar-sweetened beverages in children and adolescents: a systematic review and meta-analysis. Nutr Rev 2018;76(2):88-107. DOI: 10.1093/nutrit/nux061.

14. Bilenky T, Escolas de São Paulo Vetam até Escova de Dente para Economizar Água. [online]. 2015. [citado tem 2015 fev 4]. Disponível em: http://www1.folha.uol.com.br/cotidiano/2015/02/1584864-escolasde-sao-paulo-vetam-ate-escova-de-dente-para-economizar-agua. shtml.

15. Bellini J, Crianças São Impedidas de Escovar os Dentes em Escola de Mairinque. [online]. 2014. [citado em 2014 nov 10]. Disponível em: http://g1.globo.com/sao-paulo/sorocaba-jundiai/noticia/2014/11/ 
criancas-sao-impedidas- de-escovar- os-dentes-em- escola-demairinque.html.

16. Ohara S, Kawaguchi Y, Shinada K, et al. Evaluation of school-based dental health activities including fluoride mouth-rinsing in Hiraizumi, Japan. J Med Dent Sci 2000;47(2):133-141.

17. Goel P, Sehgal M, Mittal R. Evaluating the effectiveness of schoolbased dental health education program among children of different socioeconomic groups. J Indian Soc Pedod Prev Dent 2005;23(3):131 133. DOI: 10.4103/0970-4388.16885.

18. Macnab A, Kasangaki A. 'Many voices, one song': a model for an oral health programme as a first step in establishing a health promoting school. Health Promot Int 2012;27(1):63-73. DOI: 10.1093/heapro/ dar039.

19. Barros VA, Costa SM, Zanin L, et al. Evaluation of an educational activity in the oral health of students. Int J Dent Hyg 2017;15(1):23-29. DOI: $10.1111 /$ idh.12152.

20. Aljafari A, Gallagher JE, Hosey MT. Can oral health education be delivered to high-caries-risk children and their parents using a computer game? - a randomized controlled trial. Int J Paediatr Dent 2017;27(6):476-485. DOI: 10.1111/ipd.12286.

21. Pauleto AR, Pereira MLT, Cyrino EG. Saúde bucal: uma revisão crítica sobre programação educativas para escolares. Cien Saude Colet 2004;9(1):121-130. DOI: 10.1590/S1413-81232004000100012.

22. Damle SG, Patil A, Jain S, et al. Effectiveness of supervised toothbrushing and oral health education in improving oral hygiene status and practices of urban and rural school children: a comparative study. J Int Soc Prev Community Dent 2014;4(3):175-181. DOI: 10.4103/2231-0762.142021.

23. Cooper AM, O'Malley LA, Elison SN, et al. Primary school-based behavioural interventions for preventing caries. Cochrane Database Syst Rev 2013(5):CD009378. DOI: 10.1002/14651858.CD009378.pub2.

24. Dickson-Swift V, Kenny A, Gussy M, et al. Supervised toothbrushing programs in primary schools and early childhood settings: a scoping review. Commun Dent Health 2017;34(4):208-225. DOI: 10.1922/ CDH_4057Dickson-Swift18.

25. de Oliveira BH, Grisolia BM, Dos Santos AP. Children's toothbrushing practices recommended on the internet by pediatric dentistry associations. Pediatr Dent 2016;38(7):484-488.

26. Flório FM, Silva ASF. (Org.). Aprender brincando sobre saúde - Saúde bucal com sustentabilidade para crianças. 1. ed., Campinas: Editora Pontes; 2017. p. 218.

27. Silva ASF, Klee LS, Flório FM. Boca limpinha com água na medida certa. Flávia Martão Flório; Almenara de Souza Fonseca Silva. (Org.). Aprender brincando sobre saúde - Saúde bucal com sustentabilidade para crianças, v. 1, 1. ed., Campinas: Editora Pontes; 2017. pp. 87-105.

28. Cohen J. A power primer. Psychol Bull 1992;112(1):1. DOI: 10.1037/00332909.112.1.155.
29. Cunha C. Sustentabilidade ambiental da água consumida no município do Rio de Janeiro, Brasil. Rev Panam Salud Publica 2005;18(1):93-99. DOI: 10.1590/S1020-49892005000700003.

30. Furriela RB. Educação para o consumo sustentável. Ciclo de Palestras sobre Meio Ambiente-Programa Conheça a Educação do Cibec/ Inep-MEC/SEF/COEA 2001. 47-55.

31. Pine $C$, Adair P, Robinson L, et al. The BBaRTS healthy teeth behaviour change programme for preventing dental caries in primary school children: study protocol for a cluster randomised controlled trial. Trials 2016;17(1):103. DOI: 10.1186/s13063-016-1226-3.

32. Scherer FA. Uso racional de água em escolas públicas: diretrizes para secretarias de educação. [dissertação]. São Paulo (SP): Universidade de São Paulo; 2003.

33. Tomaz P. Economia de água para empresas e residências: um estudo atualizado sobre o uso racional da água. São Paulo: Navegar Editora; 2001. p. 112.

34. Fasola GB, Ghisi E, Marinoski AK, et al. Potencial de economia de água em duas escolas em florianópolis, SC. Ambiente Construído 2011;11(4):65-78. DOI: 10.1590/S1678-86212011000400006.

35. Ashim Hashim R, Williams $S$, Thomson WM. Oral hygiene and dental caries in 5- to- 6-year - old children in Ajman, United Arab Emirates. Int J Dent Hygiene 2013;11(3):208-215. DOI: 10.1111/idh.12011.

36. Pitts N, Duckworth RM, Marsh P, et al. Post-brushing rinsing for the control of dental caries: exploration of the available evidence to establish what advice we should give our patients. Br Dent J 2012;212(7):315-320. DOI: 10.1038/sj.bdj.2012.260.

37. Parnell C, O'Mullane D. After-brush rinsing protocols, frequency of toothpaste use: fluoride and other active ingredients. Monogr Oral Sci 2013;23:140-153. DOI: 10.1159/000350480.

38. Kose H, Sakaue K, lizuka H. Measurement of water, electronic power and gas consumption and questionnaire about act of water usage in the apartment house. In: CIB-W62 - Water supply and drainage for buildings, 30., 2004, Paris. Proceedings... Paris: CIB W62, 2004, p. 20.

39. de Melo NA, Salla MR, de Oliveira FRG, et al. Consumo de água e percepção dos usuários sobre o uso racional de água em escolas estaduais do triângulo mineiro. Ciência Engenharia 2014;23(2):01-09. DOI: 10.14393/19834071.2014.26184.

40. Wong SY, Wong LT, Mui KW. Simulations for per-capita water consumptions of appliances at secondary schools. Benchmarking 2013;1000(1):235-247.

41. Contas IBGE, econômicas ambientais da água: Brasil 2013-2015. [informativo na Internet]. 2018 [acessado 2018 Set 12]; [p. 8]. Disponível em: https://biblioteca.ibge.gov.br/visualizacao/livros/ liv101555_informativo.pdf.

42. Gonçalves RF, Coord. Uso racional de água em edificações, vol. 5, Rio de Janeiro: ABES; 2006. p. 352. (Projeto PROSAB, Edital 4). 